\author{
Doi 10.5943/ppq/7/1/7 \\ Copyright $(9$ Mushroom Research Foundation
}

\title{
Cirsosia humboldtigena sp. nov. (Lembosiaceae, Ascomycetes) on Humboldtia vahliana from Kerala, India
}

\section{Mathew KL, Nair NN and Swapna S}

PG \& Research Department of Botany, Mar Thoma College, Tiruvalla, India

Mathew KL, Nair NN, Swapna S 2017 - Cirsosia humboldtigena sp. nov. (Lembosiaceae, Ascomycetes) on Humboldtia vahliana from Kerala, India. Plant Pathology \& Quarantine 7 (1), 60-63, Doi 10.5943/ppq/7/1/7

\begin{abstract}
The plant genus Humboldtia contains six species of which five are endemic to Peninsular India. Of these, Humboldtia vahliana was found to be infected with a new species of the genus Cirsosia. Cirsosia humboldtigena sp. nov. is described and illustrated in detail to provide a consolidated account of the species known on this host genus.
\end{abstract}

Key words - black mildew - foliicolous fungi - new species

\section{Introduction}

The genus Cirsosia accommodates 15 species and one variety, all from the tropics, found mainly on Arecaceae, Chrysobalanaceae, Dipterocarpaceae, and Malpighiaceae (Hosagoudar 2010, Farr \& Rossman et al. 2015). Cirsosia manaosensis, the type species of Cirsosia, was collected from the Amazonian forest in Brazil (Arnaud et al. 1918). Cirsosia species are characterized by superficial hyphae with intercalary appressoria, the lirelliform or $\mathrm{V}-\mathrm{Y}$-shaped ascomata opening by a longitudinal fissure and 2-celled ascospores (Batista \& Maia 1960, Bezerra 2004, Hosagoudar et al. 2010, 2012). The specimens studied here were collected from different areas of the Malabar Wildlife Sanctuary, Kerala State, India and yielded what is recognised as a novel taxon and a new host association for Cirsosia. This paper describes the new species, Cirsosia humboldtigena in association with a new host Humboldtia vahliana (Caesalpiniaceae).

The genus Humboldtia is an Indo-Sri Lankan plant, comprising six species, of which five are known in India and are endemic to Southern-Western Ghats. These are mostly distributed in the evergreen forests at an altitude from 150-1250 m. Of these, Humboldtia vahliana Wight was found infected with a Cirsosia species. There are no previous reports of infection by Cirsosia on the host family Caesalpiniaceae.

\section{Materials and Methods}

Infected plant parts were selected in the field, field notes were made regarding the nature of the fungal colonies, nature of infection and the collection locality. For each collection, a separate field number was given. Each infected plant was collected separately in polythene bags along with the host twig, preferably with the reproductive parts to facilitate the identity of the host. These infected plant parts were pressed neatly and dried between blotting papers. After ensuring their dryness, they were used for microscopic study. Scrapes were taken directly from the infected host and mounted in $10 \% \mathrm{KOH}$ solution. After $30 \mathrm{~min}, \mathrm{KOH}$ was replaced by lactophenol. Both the 
mountants work well as clearing agents and made the septa visible for taking measurements. To study the entire colony in its natural condition, a drop of high quality natural coloured or transparent nail polish was applied to the selected colonies and carefully spread with the help of a fine brush without disturbing the colonies. Colonies with hyper parasites showing a woolly nature were avoided. The treated colonies along with their host plants were kept in a dust free chamber for 30 minutes. When the nail polish on the colonies dried fully, a thin, colourless or slightly apple rose coloured (depending upon the colour tint in the nail polish) film or flip was formed with the colonies firmly embedded in it. In case of soft host parts, the flip was lifted off with a slight pressure on the opposite side of the leaves and just below the colonies. In case of hard host parts, the flip was eased off with the help of a razor or scalpel. A drop of DPX (mixture of distyrene (a polystyrene), a plasticizer (tricresyl phosphate), and xylene) was spread on a clean slide and the flip was spread properly on it. One or two more drops of DPX were added additionally on the flip and a clean cover glass was placed over it. By gently pressing on the cover glass, excessive amount of DPX was removed after drying. Care was taken to avoid air bubbles. These slides were labeled and placed in a dust free chamber for one to two days for drying. These permanent slides were then used for further studies. For innate fungi, sections were made and stained in cotton blue. After the study of each collection, part of the material was retained in the regional herbarium, Mar Thoma College Herbarium, Thiruvalla, MTCHT.

\section{Taxonomy}

Cirsosia humboldtigena Lini K. Mathew, Neeta N. Nair and Swapna S. sp. nov.

Fig 1 Index Fungorum Number: IF552781.

Etymology - named after the host genus, Humboldtia.

Colonies hypophyllous, dense, black, up to $2 \mathrm{~mm}$ in diam. Hyphae straight to undulate, brown, branching alternate to opposite to irregular at acute angles, loosely reticulate, cells $38-50 \times$ 2.4-4.8 $\mu \mathrm{m}$. Appressoria intercalary, ovate, often slightly laterally, 2.6-5.4 $\mu \mathrm{m}$ in diam. Thyriothecia scattered, initially round and ovate, elongated at maturity with a longitudinal slit at the centre, 200-480 × 150-280 $\mu \mathrm{m}$, margin crenate to fimbriate, fringed hyphae straight, closely aggregated and parallel, devoid of intercalary appressoria. Asci numerous, globose, octosporous, 30-42 $\mu \mathrm{m}$ in diam. Ascospores obovate, conglobate, uniseptate, deeply constricted at the septum, cinnamon-brown, 19-21 × 13-15 $\mu \mathrm{m}$, wall echinulate. Pycnothyria many, similar to thyriothecia; pycnothyriospores deep brown, pyriform, slightly papillate, $17-19 \times 11-13 \mu \mathrm{m}$.

Material examined - India, Kerala, Kozhikode, Malabar Wildlife Sanctuary, Janakikadu, on living leaves of Humboldtia vahliana (Caesalpiniaceae), 15 Oct 2013, Lini K. Mathew, MTCHT 77 (holotype)

\section{Discussion}

Intercalary appressoria and elliptical thyriothecia with longitudinal dehiscence are the characteristics of the genus Cirsosia. Sixteen species and one variety of Cirsosia have now been described on six host families (Hosagoudar \& Pillai 1994, Hosagoudar 2010, Hosagoudar et. al. 2011, Hofmann \& Piepenbring 2014, Farr \& Rossman 2015, Firmino et al. 2016): Dipterocarpaceae (5 species), Arecaceae (4), Chrysobalanaceae (3, including one variety), Malpighiaceae (2), Burseraceae (1) and Lauraceae (1). There is no record of the same Cirsosia species being found on two different host families (Hosagoudar 2010, Farr \& Rossman 2015, Firmino et al. 2016).

Based on the host specificity, colony morphology, size and morphology of mycelium and ascospores, the present species can confidently be described as a new species. 

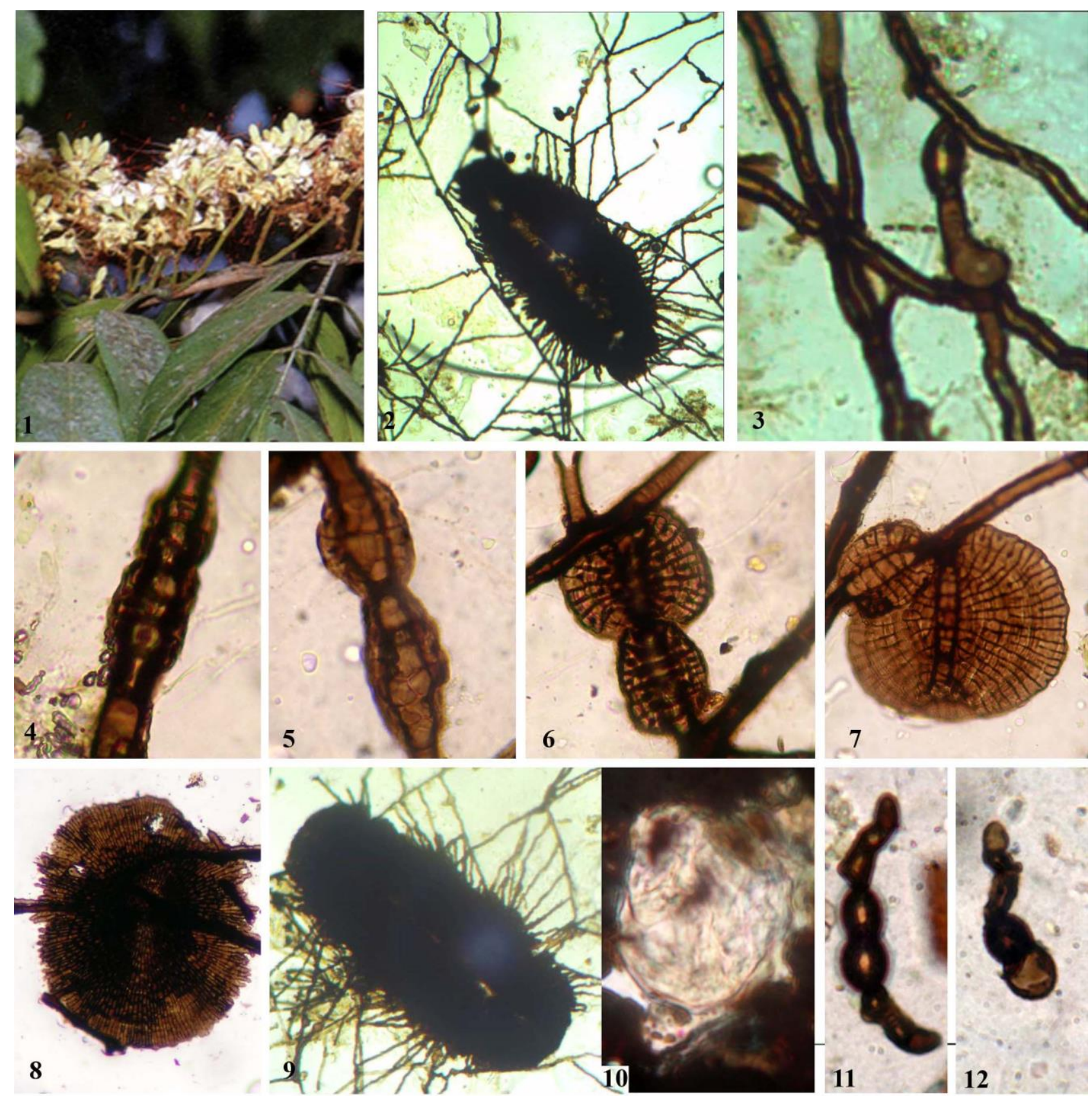

Fig. 1 - Cirsosia humboldtigena sp. nov. 1. Infected leaves of Humboldtia vahliana, 2. Colony with thyriothecia, 3. Mycelium with intercalary appressoria, 4-8. Different stages of development of thyriothecia, 9. Mature thyriothecium, 10. Ascus. 11-12. Germinating ascospores

\section{Acknowledgements}

We are grateful to K. Jacob, Principal and Dr. Elizabeth T. Mangatt, HOD Botany, Mar Thoma College; Registrar, Mahatma Gandhi University Kottayam for the facilities.

\section{References}

Arnaud G 1918 - Les Astérinées. Annales de l'École Nationale d'Agriculture de Montpellier 16, $1-288$.

Batista AC, Maia H 1960 - Cirsosia Arnaud e Cirsosina Bat. - novas espécies. Revista de Biologia Lisboa 2, 115-136. 
Bezerra JL 2004 - Taxonomia de ascomicetos: revisão da ordem Asterinales. Revista Anual de Patologia de Plantas 12, 91-115.

Farr DF, Rossman AY 2015 - Fungal Databases, Systematic Mycology and Microbiology Laboratory, ARS, USDA. http:// nt.ars-grin.gov/fungaldatabases/.

Firmino AL, Inácio CA, Pereira OL, Dianese JC 2016 - Additions to the genera Asterolibertia and Cirsosia (Asterinaceae, Asterinales), with particular reference to species from the Brazilian Cerrado. IMA Fungus 7(1), 9-28. doi:10.5598/imafungus.2016.07.01.02

Hofmann TA, Piepenbring M 2014 - New records of plant parasitic Asterinaceae (Dothideomycetes, Ascomycota) with intercalary appressoria from Central America and Panama. Tropical Plant Pathology 39, 419-427.

Hosagoudar VB 2010 - Notes on the genera Asterolibertia and Cirsosia (Fungi: Ascomycota). Journal of Threatened Taxa 2, 1153-1157.

Hosagoudar VB. 2012 - Asterinales of India. Mycosphere 2, 617-852.

Hosagoudar VB, Pillai M 1994 - Two interesting Cirsosia species on Calamus from India. Mycological Research 98, 127-128.

Hosagoudar VB, Thomas J, Agarwal DK 2011 - Four new asterinaceous members from Kerala, India. Taprobanica 3, 15-17. 